University of Nebraska - Lincoln

DigitalCommons@University of Nebraska - Lincoln

Roman L. Hruska U.S. Meat Animal Research

U.S. Department of Agriculture: Agricultural Center

Research Service, Lincoln, Nebraska

2000

\title{
Porcine Erythropoietin Receptor: Molecular Cloning and Expression in Embryonic and Fetal Liver
}

\author{
P. L. Pearson \\ USDA-ARS
}

T. P. L. Smith

USDA-ARS, tim.smith@usda.gov

T. S. Sonstegard

USDA-ARS

H. G. Klemcke

USDA-ARS

R. K. Christenson

USDA-ARS

See next page for additional authors

Follow this and additional works at: https://digitalcommons.unl.edu/hruskareports

Pearson, P. L.; Smith, T. P. L.; Sonstegard, T. S.; Klemcke, H. G.; Christenson, R. K.; and Vallet, J. L., "Porcine Erythropoietin Receptor: Molecular Cloning and Expression in Embryonic and Fetal Liver" (2000). Roman L. Hruska U.S. Meat Animal Research Center. 248.

https://digitalcommons.unl.edu/hruskareports/248

This Article is brought to you for free and open access by the U.S. Department of Agriculture: Agricultural Research Service, Lincoln, Nebraska at DigitalCommons@University of Nebraska - Lincoln. It has been accepted for inclusion in Roman L. Hruska U.S. Meat Animal Research Center by an authorized administrator of DigitalCommons@University of Nebraska - Lincoln. 


\section{Authors}

P. L. Pearson, T. P. L. Smith, T. S. Sonstegard, H. G. Klemcke, R. K. Christenson, and J. L. Vallet 


\title{
Porcine erythropoietin receptor: molecular cloning and expression in embryonic and fetal liver
}

\author{
P.L. Pearson, T.P.L. Smith, T.S. Sonstegard, H.G. Klemcke, \\ R.K. Christenson, J.L. Vallet*
}

USDA, ARS, Roman L. Hruska U.S. Meat Animal Research Center, Clay Center, NE 68933, USA

Received 24 January 2000; accepted 20 April 2000

\begin{abstract}
The full coding sequence for porcine erythropoietin receptor (EPOR) was elucidated using reverse transcription polymerase chain reaction (PCR) (rtPCR) and $3^{\prime}$ and $5^{\prime}$ rapid amplification of cDNA ends (RACE) procedures. Total RNA collected from Day 30 fetal liver was used as starting material. A 1843 bp sequence was obtained from which could be inferred a 509 amino acid protein which was $79-85 \%$ identical to the amino acid sequence of erythropoietin receptor from other species. Total RNA samples collected from white crossbred intact, white crossbred UHO and Meishan gilts on Days 24, 30 and 40 of gestation were subjected to Northern blotting using porcine EPOR cDNA as probe. Results indicated that (1) a major and two minor forms of mRNA are present, (2) fetal liver mRNA concentrations for EPOR are low on Day 24 of gestation and increase dramatically by Day 30 and (3) mRNA concentrations for EPOR tended to be decreased by intrauterine crowding. () 2000 Elsevier Science Inc. All rights reserved.
\end{abstract}

\section{Introduction}

Investigations into uterine crowding and fetal survival in swine indicate an approximate $20-40 \%$ loss of fetuses between Day 25 and Day 50 of gestation [1-3]. Previous work from our laboratory indicates that this time period corresponds to a period of rapid expansion and maturation of the blood supply. It was further demonstrated that intrauterine crowding decreased hematocrit and hemoglobin on Day 40 [4]. Thus, investigations of the erythro-

* Corresponding author. Tel.: +1-402-762-4187; fax: +1-402-762-4382.

E-mail address: vallet@email.marc.usda.gov (J.L. Vallet). 
poiesis process will not only increase our knowledge of fetal development and physiology, but may lead to intervention strategies designed to decrease losses due to intrauterine crowding and increase litter size in swine.

In adults, the concentration of circulating red blood cells is controlled by the hormone erythropoietin (EPO). Acting through the EPO receptor (EPOR), EPO stimulates erythropoiesis by promoting the development of committed erythroid cells, either through inhibition of apoptosis or increased cell division (reviewed in Fisher [5]). The erythropoietin receptor (EPOR) is a $66 \mathrm{Kd}$, type I transmembrane protein in the cytokine receptor super family, which includes the receptors for IL-2, IL-6 and leptin [6]. The cDNA sequences for human, rat and mouse EPOR have been reported [7-9]. Studies in these species have investigated the role of EPOR in blood production and its intracellular signal transduction (reviewed in 5, 10). Genetic knockouts of EPOR [11] or EPO itself [12] in mice lead to embryonic death due to anemia by approximately Day 13.5 of gestation. Thus, EPOR, because of its central role in controlling erythropoiesis, may be an important factor in embryonic/fetal survival in swine.

We previously reported that the process of erythropoiesis may be accelerated in Meishan fetuses. The Meishan breed is highly prolific [13], making it useful for examination of factors that might influence factors affecting litter size. Thus, comparisons between white crossbred gilts and Meishan gilts may provide clues to adaptations in the Meishan that lead to increased litter size.

The objectives of this study were to: 1) clone the cDNA for porcine (p) EPOR, 2) characterize the expression of EPOR mRNA in embryonic and fetal porcine liver tissue and 3) compare erythropoietin receptor expression in fetal liver collected from normal white crossbred embryos, crowded white crossbred embryos and Meishan embryos. Unilateral hysterectomy ovariectomy (UHO) was used to induce intrauterine crowding [14].

\section{Materials and methods}

\subsection{Partial clones 1 and 2}

Primers (Table 1) were generated against a consensus EPOR sequence after aligning the known cattle (GenBank Acc. Numbers U61398 and U61399), human [7], mouse [9] and rat [8] sequences. Fetal pig liver was obtained at Day 30 of gestation, rapidly frozen in liquid $\mathrm{N}_{2}$ and stored at $-80^{\circ} \mathrm{C}$ until processed to extract total RNA. Total RNA was isolated using the column method (RNAeasy; Qiagen, Valencia, CA). Total RNA (1 $\mu \mathrm{g})$ was reverse transcribed using $1 \mu \mathrm{M}$ oligo dT18 primer, $1 \mu \mathrm{M}$ dNTPs and reverse transcriptase (Promega, Madison, WI) for $1 \mathrm{hr}$ at $37^{\circ} \mathrm{C}$. The resulting cDNA was used as template in $20 \mu \mathrm{l} \mathrm{PCR}$ reactions containing $10 \mathrm{U}$ Taq polymerase, $1.5 \mathrm{mM} \mathrm{MgCl}_{2}, 0.1 \%$ Triton-X, $0.1 \mathrm{mM}$ DTT, $50 \mathrm{mM} \mathrm{KCl}, 0.25 \mathrm{mM}$ dNTP's, and $2 \mu \mathrm{M}$ of primers (F1 and R2, Table 1). Samples were amplified using 1 cycle of $95^{\circ} \mathrm{C}, 4$ min incubation to denature followed by 30 cycles of the following steps: $95^{\circ} \mathrm{C} 1 \mathrm{~min} ; 58^{\circ} \mathrm{C}$ for $1 \mathrm{~min}$., and $72^{\circ} \mathrm{C}$ for $1 \mathrm{~min}$. This was followed by a $72^{\circ} \mathrm{C}$ incubation for $10 \mathrm{~min}$. The resulting product was cloned into the PCRII vector according to the instructions included with the PCRII kit (Invitrogen, Carlsbad CA). Colonies containing the cloned insert (clone 1) were then sequenced using automated sequencing 
Table 1

Primer sequences used for amplification, cloning and sequencing of the porcine erythropoietin receptor. Abbr: RT-reverse transcriptase, amp-amplification, reamp-reamplification, RACE-rapid amplification of cDNA ends

\begin{tabular}{|c|c|c|}
\hline Primer name & Primer sequence $\left(5^{\prime}\left(3^{\prime}\right)\right.$ & Used for \\
\hline Oligo dT18 & TTTTTTTTTTTTTTTTTT & clones 1,2 RT \\
\hline $\mathrm{F} 1$ & TTCTCTTACCAGCTCGAGGGTG & clone 1 \\
\hline $\mathrm{R} 2$ & GAGCACGAGGATGAGGGAGA & clone 1 \\
\hline Epor3.F2 & AACGCGCTACACCTTCATG & clone 2 \\
\hline Epor3.R2 & AAGGGTTGGAGTAGGGGC & clone 2 \\
\hline $2-1$ & TCCGTCTCGCCGTTAGTG(T18) & 3'RACE RT \\
\hline $2-2$ & TCCGTCTCGCCGTTAGTG & 3'RACE amp/reamp \\
\hline Epor3.F5 & TTGTGGTGTCTGACTCTGGC & 3'RACE amp \\
\hline Epor3.F6 & GTGGCCCCTACTCCAACC & $3^{\prime} \mathrm{RACE}$ reamp \\
\hline Epor5.7 & GGGTCTAGCAGCACCACTTC & 5'RACE RT \\
\hline Xba-lnk & P-TCTAGAGTCAAGTCAGGCAATGTCGTT-NH2 & ligated to cDNA \\
\hline Xba-com & AACGACATTGCCTGACTTGAC & $5^{\prime} \mathrm{RACE}$ amp/reamp \\
\hline Epor5.8 & GAGCCAGCGCAGTACCAC & 5'RACE amp \\
\hline Epor5.9 & GTTCACCTCATGCGGATAAGG & 5'RACE reamp \\
\hline Eporall.F1 & GGTCAGCTGTGTCCGGTG & full length clone \\
\hline Eporall.F2 & GACCCAGCTGTGGACTGTG & full length clone \\
\hline Eporall.R & TGTGACTTTCTGAGCAGGATG & full length clone \\
\hline M13-21 & TGTAAAACGACGGCCAGT & sequence confirmation \\
\hline M13 rev & CAGGAAACAGCTATGACCAT & sequence confirmation \\
\hline $\mathrm{F} 2 \mathrm{~A}$ & GCGTTTCTGGTGGTCGCTG & sequence confirmation \\
\hline 84F3 & TCATCCTCGTGCTCATCTTG & sequence confirmation \\
\hline 84R1 & GGTACAAGTACTTCAGGTGGGG & sequence confirmation \\
\hline $3 F 4$ & TATCCTGGATCCCAGCTCAC & sequence confirmation \\
\hline $\mathrm{R} 2 \mathrm{~A}$ & GAGCACGAGGATGAGGGAGG & sequence confirmation \\
\hline GAPDH.R & GAAGCAGGGATGATGTTCTGG & GAPDH RT and amp \\
\hline GAPDH.F & CACGACCATGGAGAAGGC & GAPDH amp \\
\hline
\end{tabular}

(ABI 377, Perkin Elmer, Norwalk, CT). To generate clone 2, the cDNA resulting from reverse transcription was amplified using primers Epor 3F2 and Epor 3R2 (Table 1) using the above conditions. The resulting product was then cloned and sequenced.

\section{2. $3^{\prime}$ race (clone 3 )}

Total RNA $(1 \mu \mathrm{g})$ from Day 30 fetal liver was reverse transcribed using Primer 2-1 (Table 1). The resulting cDNA was amplified as described previously using primers F5 and 2-2 (Table 1). The resulting product was reamplified using primers F6 and 2-2 (Table 1). The resulting single band was cloned into PCRII and sequenced as previously described.

\section{3. $5^{\prime}$ race (clone 4$)$}

Total RNA $(5 \mu \mathrm{g})$ was reverse transcribed in a $50 \mu \mathrm{l}$ reaction using primer 5.7 (Table 1) as described previously. For 5'-RACE, a modification [15] of the procedure of Apte and Siebert [16] was used. Briefly, after reverse transcription, the RNA was degraded and cDNA was separated from free nucleotides using glass milk as described [15]. The recovered cDNA 
was then lyophilized and redissolved in $10 \mu \mathrm{l}$ water. One $\mu \mathrm{l}$ of the resulting solution was then ligated to the Xba-LNK primer (Table 1) using T4 RNA ligase and the conditions previously described. One $\mu$ l of the resulting solution was then used as template and amplified using primers 5.8 and Xba-com. This PCR product was then reamplified with primers 5.9 and Xba-com. The resulting product was electrophoresed on a $1.5 \%$ agarose gel, the band corresponding to the correct size was isolated using glass milk (Sigma, St. Louis, MO) and the isolated fragment was ligated into PCRII and sequenced as previously described.

\subsection{Full-length clone}

To confirm the entire EPOR sequence, the primers eporall.F1 and eporall.R were generated and used to amplify the entire coding region. Total RNA from a Day 30 fetal liver was reverse transcribed using the eporall.R primer and then these primers were used to amplify the resulting cDNA. A $1.8 \mathrm{~kb}$ band corresponding to the correct size for EPOR was gel purified as described previously and ligated into PCRII. Three positive clones were fully sequenced in both directions using primers M13-21, M13 rev, F2a, 5.8, 84F3, 84R1, 3F4 and R2a (see Table 1).

\subsection{Northern analysis}

Ten $\mu \mathrm{g}$ of total RNA isolated from Day 24, 30 and 40 fetal liver tissue from white crossbred intact, white crossbred unilateral hysterectomized-ovariectomized (UHO) and Meishan intact pigs (4 per age/group combination), was electrophoresed in a $1.2 \%$ agarose, $1 \times \mathrm{MOPS} /$ formaldehyde gel, capillary blotted onto nylon membrane (Hybond, N-Amersham, St. Louis, MO), UV cross linked and stored at $-20^{\circ} \mathrm{C}$. In the UHO surgical procedure, one uterine horn and one ovary are removed. Due to ovarian compensation, ovulation rate is unaffected by this treatment, but the developing embryos are forced to gestate in half the normal uterine space, creating a crowded intrauterine environment. Probe was generated using primers $\mathrm{F} 1$ and $\mathrm{R} 2$ and the initial EPOR clone as template in a PCR reaction as described above substituting $\left[{ }^{32} \mathrm{P}\right] \mathrm{dCTP}$ for dCTP. Blots were prehybridized in Rapid Hybe (Amersham) at $65^{\circ} \mathrm{C}$ for $1 \mathrm{hr}$. Probe was then added $\left(1 \times 10^{6} \mathrm{CPM} / \mathrm{ml}\right)$ and blots were incubated for $2 \mathrm{hr}$ at $65^{\circ} \mathrm{C}$. Blots were rinsed twice in $2 \times \mathrm{SSC}(1 \times \mathrm{SSC}=.15 \mathrm{M} \mathrm{NaCl}, .015$ $\mathrm{M} \mathrm{Na}$ Citrate), $0.1 \% \mathrm{SDS}$, washed twice for $15 \mathrm{~min}$ in $2 \times \mathrm{SSC}, 0.1 \% \mathrm{SDS}$ at $65^{\circ} \mathrm{C}$, in $0.5 \times$ $\mathrm{SSC}, 0.1 \% \mathrm{SDS}$ at $55^{\circ} \mathrm{C}$ and $65^{\circ} \mathrm{C}$ for $15 \mathrm{~min}$ each and placed on film for $72 \mathrm{hr}$.

The glyceraldehyde phosphate dehydrogenase (GAPDH) cDNA probe used [14] was generated using the GAPDH.F and GAPDH.R (Table 1) primers in the presence of $\left[{ }^{32} \mathrm{P}\right] \mathrm{CTP}$ as described for the erythropoietin receptor. Blots were stripped of EPOR probe ( $1 \mathrm{mM}$ Tris, $1 \mathrm{M}$ EDTA; $2 \mathrm{hr}$ at $80^{\circ} \mathrm{C}$ ) and then prehybridized for $2 \mathrm{hr}$ at $65^{\circ} \mathrm{C}$ with Rapid Hybe and hybridized with $1 \times 10^{6} \mathrm{CPM}$ radiolabelled probe per $\mathrm{ml}$ at $65^{\circ} \mathrm{C}$ for $2 \mathrm{hr}$. Blots were then washed twice with $2 \times \mathrm{SSC}, 0.1 \%$ SDS. To quantitate changes in mRNA, autoradiographs were analyzed by densitometry using a laser densitometer (Ultrascan XL, Pharmacia LKB, Piscataway, NJ). 

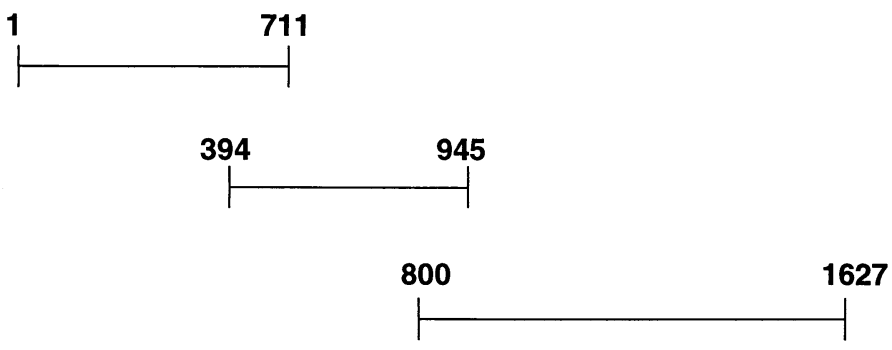

\section{5' RACE}

clone 1

clone 2

\section{$1607 \quad 1843$}

\section{3' RACE}

53

1843

confirmation

Fig. 1. The relationships among the different erythropoietin receptor clones is diagrammed schematically. Primers used for the isolation of each clone are described in Table 1.

\subsection{Statistical analysis}

Densitometric data for the major EPOR mRNA band was analyzed by analysis of variance using a model which included GAPDH densitometric values as a covariate along with effects of day of gestation, breed/treatment (white crossbred intact, UHO and Meishan intact) and the day by breed/treatment interaction. Sets of orthogonal contrasts were employed to more fully evaluate day and breed/treatment effects. Two sets were used. Generally, white crossbred intact was compared with Meishan intact (effect of breed) followed by a comparison of these two groups combined with the white crossbred UHO treatment group (effect of UHO). However, in the event that the first contrast was significant, the white crossbred intact group was compared with white crossbred UHO group (effect of UHO) and then the two combined were compared with the Meishan group (effect of breed).

\section{Results}

The size of each individual clone and their relationship to each other is diagrammed in Fig. 1. A total of 1843 nucleotides of the sequence for the pEPOR mRNA (Genbank Acc. \#AF274305) was obtained and the sequence and its inferred amino acid sequence are shown in Fig. 2. The sequence encodes for a protein of 509 amino acids and includes 159 and 154 nucleotides in the 5' and 3' untranslated regions (UTR), respectively. No consensus sequence of translation initiation was observed in the $5^{\prime}$ untranslated region [17]. The inferred amino acid sequence is aligned with rat, mouse and human sequences in Fig. 3. The open reading frame contains one putative N-glycosylation site in the extracellular domain of the peptide (AA 184), nine conserved cysteine residues, and the WSAWSE hallmark of cytokine receptors. A putative signal peptide (aa 1 to 24 ) and a single transmembrane domain (aa 251 


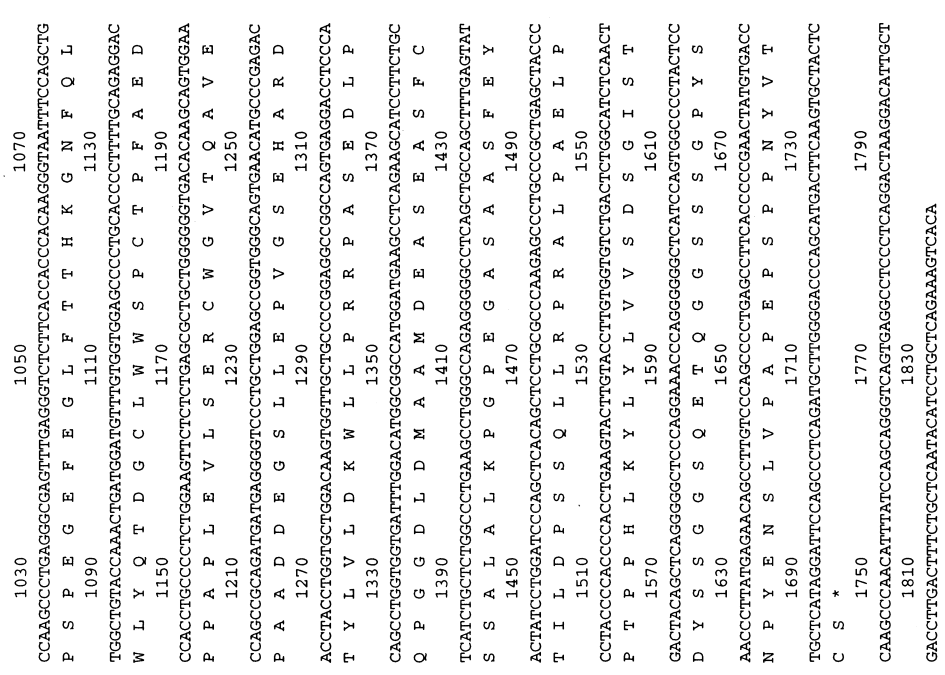




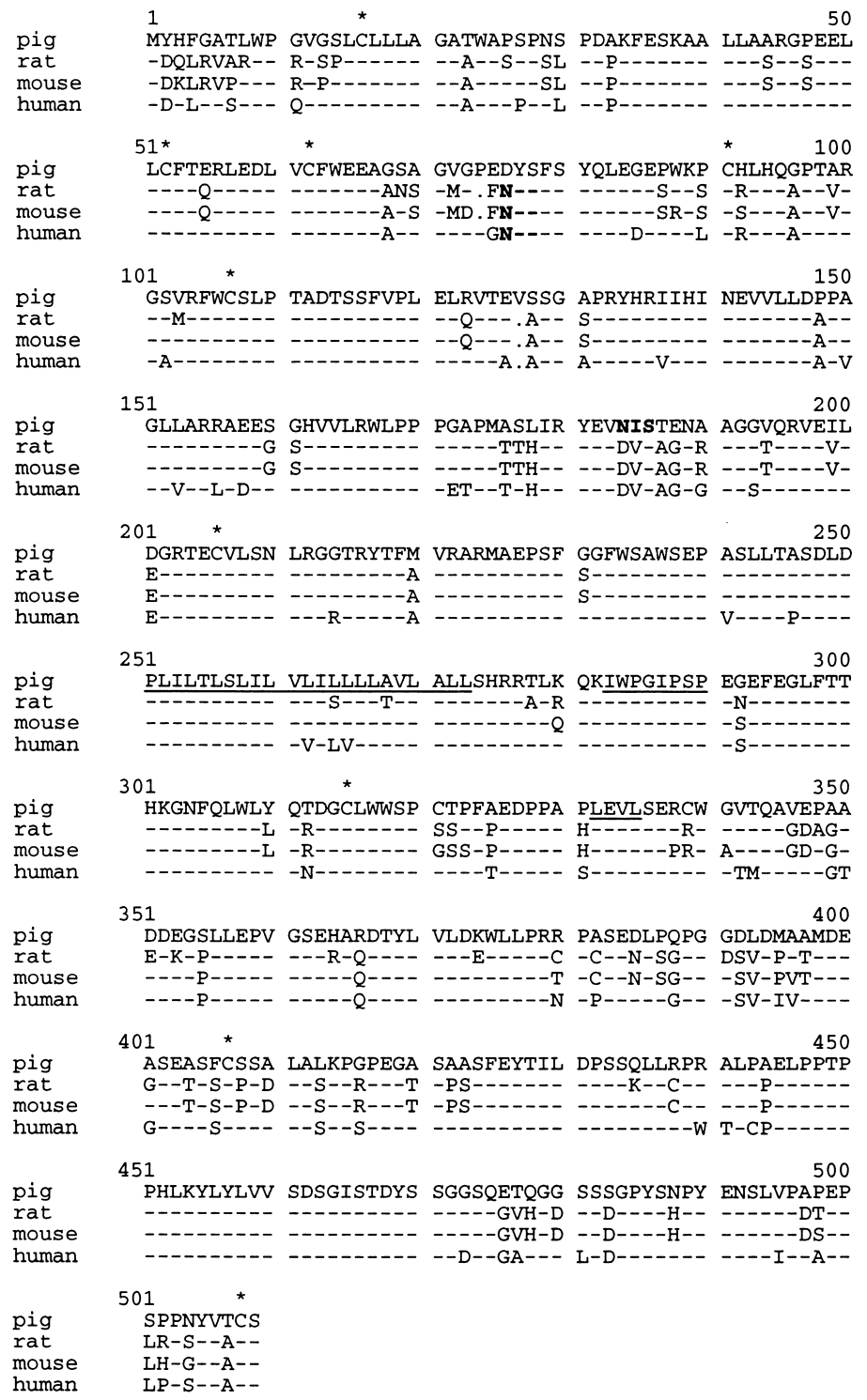

Fig. 3. The inferred amino acid sequence for porcine erythropoietin receptor is shown aligned with the previously reported sequences for rat, mouse and human erythropoietin receptor. A dashed line indicates identity. Conserved cysteine residues are indicated with an *. The transmembrane domain, box 1 and 2 are the first, second and third underlined regions, respectively. Potential N-linked glycosylation sites are in bold letters.

to 273) are also present as expected. Overall, the inferred amino acid sequence ranged from 79 to $85 \%$ identity with previously reported receptors from other species (Table 2). However the identity among sequences was not uniformly distributed over the entire coding sequence. Large regions of $100 \%$ conservation included from amino acids 104 to 122, 247 to 261, 293 to 309 and from 445 to 472 . Finally, the nucleotide sequence of the 5' UTR and 3' UTR were 
Table 2

Percent sequence identity between the inferred amino acid sequences for erythropoietin receptor from the pig, rat, mouse and human

\begin{tabular}{llll}
\hline & Human & Mouse & Rat \\
\hline Pig & 84.6 & 80.7 & 78.9 \\
Rat & 80.7 & 94.2 & \\
Mouse & 81.9 & & \\
\hline
\end{tabular}

91\%, and $71 \%$ identical (Fig. 4) with the corresponding nucleotide sequences for human EPOR, suggesting that the $5^{\prime}$ and $3^{\prime}$ UTR may contain conserved control elements responsible for regulating either transcription or translation.

Northern analysis indicated a molecular weight of $2.5 \mathrm{Kpb}$ for the most abundant form of pEPOR mRNA along with two other much less abundant minor forms. Expression was low on Day 24 and then increased dramatically on Day 30 and Day 40 of gestation (Fig. 5). Densitometry indicated that the UHO treatment group had lower overall expression of pEPOR mRNA that approached statistical significance $(n=4, \mathrm{P}=0.06)$ when compared to the two intact groups combined (Fig. 6).

\section{Discussion}

This study represents the first reported cloning of pEPOR and the first known examination of pEPOR expression in the fetal liver of the pig. Results indicate that expression of $\mathrm{pEPOR}$ mRNA (at detectable levels) is initiated between Day 24 and Day 30 of gestation in the pig fetal liver and remains relatively constant between Day 30 and Day 40.

Comparison of the nucleotide sequences and inferred amino acid sequences between species indicates that both the erythropoietin receptor protein and the untranslated regions within the mRNA are highly conserved. All of the regions of 100\% homology within the amino acid sequence of the protein correspond to important functional regions of the receptor. The first region brackets a phenylalanine residue (F 117) which was shown to be important for interaction with ligand [18]. Thus the conservation in this region is likely necessary to preserve some aspect of the ligand binding site. The second corresponds to the external border and first half of the transmembrane domain. It seems unusual that the transmembrane domain should be highly conserved, because replacement of these residues by other hydrophobic amino acids would be expected to have little influence on the ability of this region to behave as a transmembrane domain. The signal sequence, which also functions to span the membrane, is not conserved. The conservation in the transmembrane region therefore may suggest that it may do more than simply span the membrane. The third conserved region is located near the box 1 region of the cytoplasmic side of the receptor, a region that has been shown to be conserved among various cytokine receptors, and is thought to be important in intracellular signaling [18]. Thus, this conserved region is a necessary part of the interaction between the erythropoietin receptor and intracellular kinases which carry out the changes that occur within the cell in response to the binding of erythropoietin $[10,20]$. 
A.

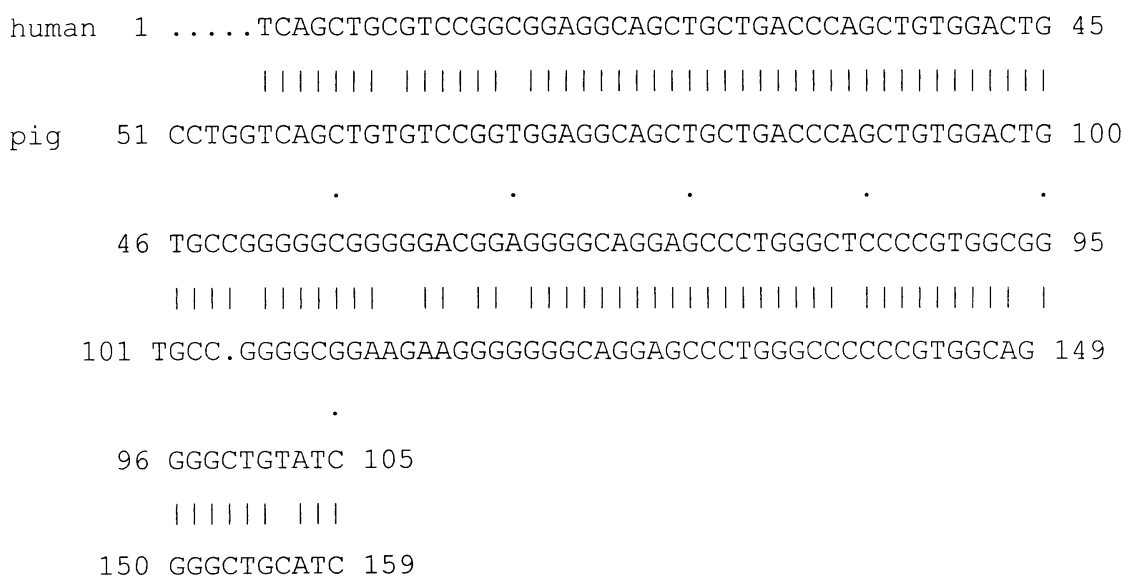

B.

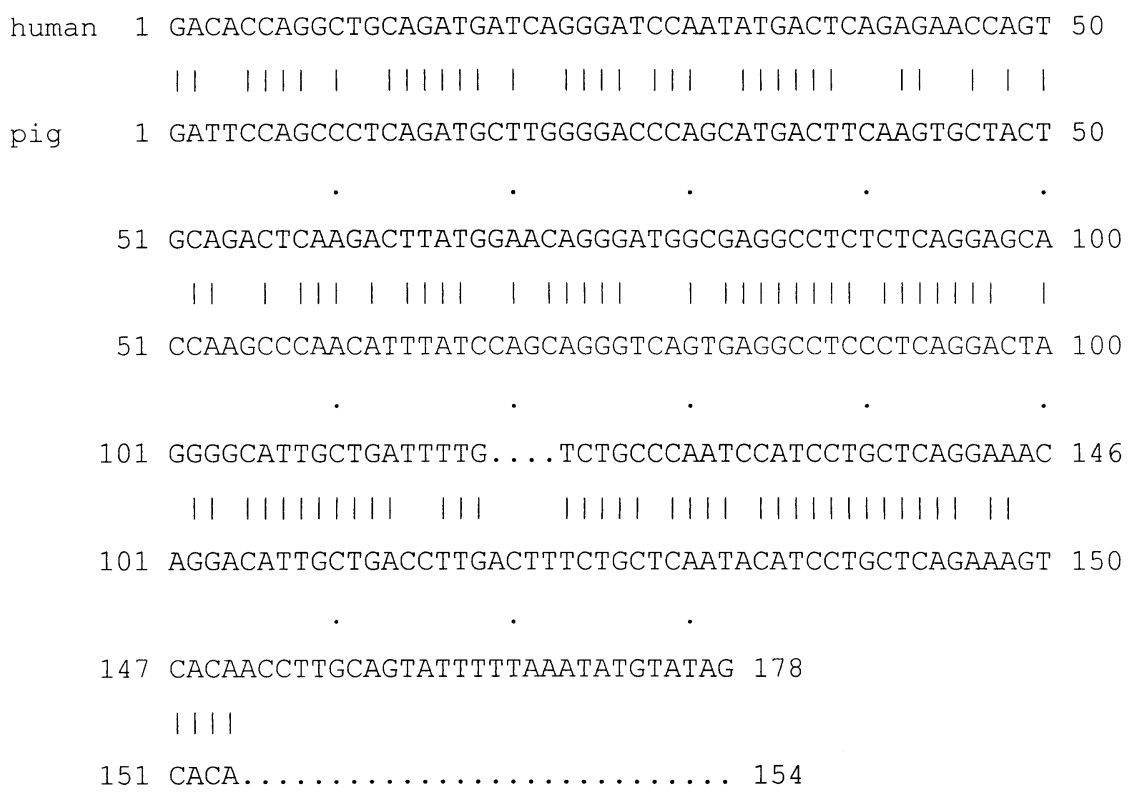

Fig. 4. The 5' (A) and 3' (B) untranslated regions for the porcine fetal liver erythropoietin receptor aligned with the same regions for the human erythropoietin receptor are illustrated. They were 91 and $71 \%$ identical, respectively. 


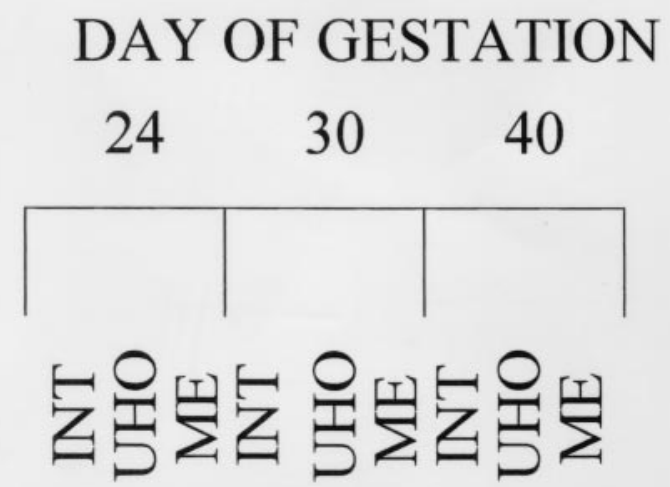

\section{Erythropoietin receptor}

\section{Glyceraldehyde phosphate dehydrogenase}

$-2.5 \mathrm{~kb}$

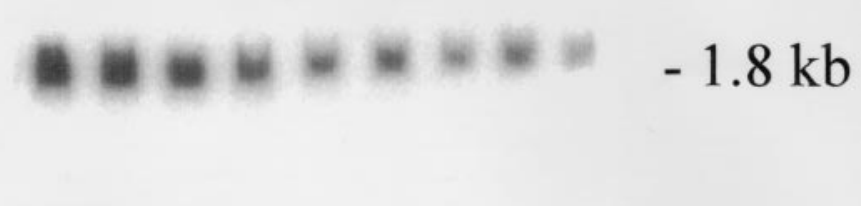

Fig. 5. A representative Northern blot for fetal liver erythropoietin receptor and glyceraldehyde phosphate dehydrogenase mRNA is illustrated. Treatments were intact white crossbred (INT), unilaterally hysterectomized ovariectomized white crossbred (UHO) and Meishan (ME). See Fig. 6 for densitometric evaluation of these blots.

The final region is reported to interact with an intracellular phosphatase $[8,10]$. It was reported that several genetic mutations in humans either truncating or modifying this region result in benign increases in red blood cell concentrations [21-23]. In the pig, changes in several codons could potentially generate mutations similar to those described in humans. Single nucleotide mutations (TCA to TGA; CAG to TAG; and AGA to TGA) of codons 434(S), 435(Q) or 440(R), respectively, could all result in truncations of this region. If increased concentration of red blood cells is beneficial to uterine capacity, these possible mutations could be useful in increasing litter size in swine. A search for possible beneficial mutations within this region is currently in progress.

The conservation between species extends into the $5^{\prime}$ and $3^{\prime}$ UTR, suggesting that these regions may be important in the control of the amount of receptor mRNA that is transcribed or translated. The elaboration of erythropoietin receptor on cells of the erythropoietic line is required once cells are committed to the erythropoietic pathway [12]. Analysis of the 5' UTR using signal scan [24] suggested potential binding sites for part of an enhancer region reported for the human transferrin gene (25; bases 52-59) and two potential SP1 [26] sites (bases 106-111 and 121-126). Both potential SP1 sites are conserved, it cannot be determined whether the transferrin gene enhancer is conserved because the human sequence is lacking. Analysis of RNA folding of the 3' UTR indicated a possible stem-loop structure (bases 1806-1841), which includes the polyadenylation site (AATACA; bases 1819-1824). 


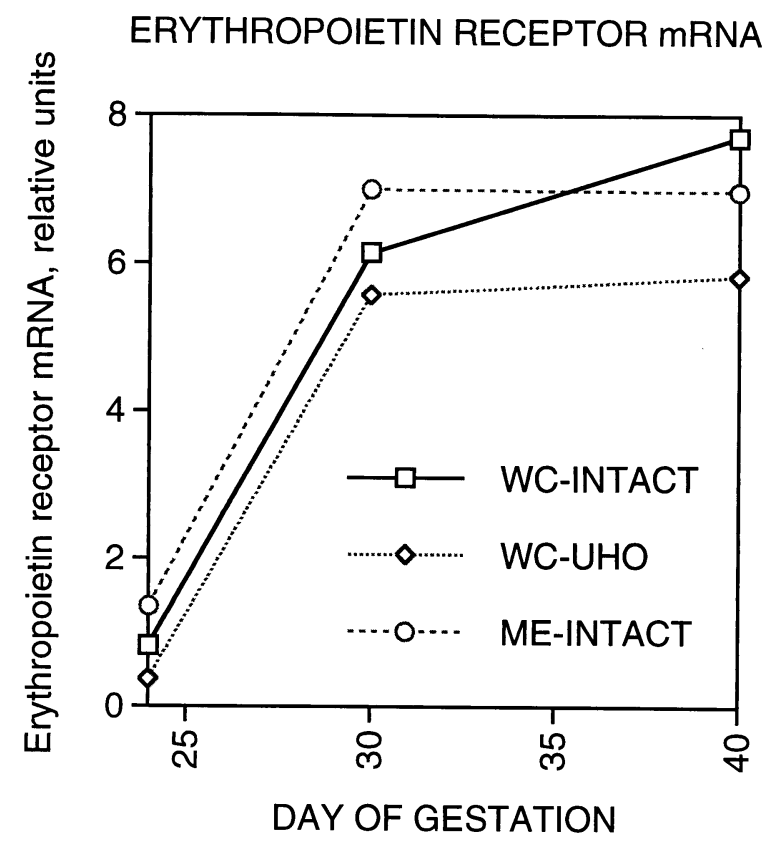

Fig. 6. Least squares means $(n=4)$ for fetal liver erythropoietin receptor mRNA from white cross (WC) intact, unilateral hysterectomized-ovariectomized (UHO) and Meishan (ME) intact gilts are illustrated. The pooled standard error of each mean from analysis of variance was 1.33 relative units. Expression was lower $(\mathrm{P}=0.06)$ for UHO compared to white cross and Meishan intact treatment groups.

However, this stem loop structure is not conserved in the human epor cDNA. Whether the $5^{\prime}$ and 3' UTR contain sequences which govern the onset of erythropoietin expression requires further investigation.

The dramatic increase in EPOR expression in fetal liver on Day 30 of pregnancy coincides with a shift from nucleated immature cells to nonnucleated cells in the circulating blood and also with the fetal liver becoming a major site of erythropoiesis. Fetal liver erythropoiesis in mice is completely dependent on both EPO and EPOR, while the development of primitive nucleated blood cells which precedes this period does not require either $[11,12]$. It is likely that the increase in fetal liver EPOR is a direct result of the immature red blood cells, which highly express EPOR, becoming resident in the liver at this time. However, it was reported that erythropoietin is a mitogen for fetal liver stromal cells [27]. Because dramatic growth of the liver also occurs at this time [4], some of the increase in receptor mRNA may be from liver cells. Thus, EPO and EPOR could also be involved in the maturation of the fetal liver into a hematopoietic organ. Further studies are needed to determine which cells have EPOR and the role of EPOR in liver and blood cell development.

The presence of multiple mRNA sizes is consistent with previous reports [28-30]. Alternative splicing of the gene for EPOR causes generation of two truncated forms of EPOR. The first is a secreted form, the alternative splicing introduces a stop codon ahead of the transmembrane domain. The second introduces a stop codon truncating part of the cytoplasmic domain. The function of the secreted form is not known. The second truncated 
form is the dominant form in immature erythroid progenitor cells [31]. The ratios of the bands to each other does not appear to change during the period examined. Whether the multiple EPOR mRNA sizes correspond to truncated forms of the receptor, and the physiological relevance of these potential alternate forms of EPOR mRNA remains to be determined.

Although not statistically significant, a trend toward lower pEPOR gene expression in the UHO group was observed. Our previous investigations suggested that the overall efficiency of erythropoiesis was unaffected by intrauterine crowding; however, a positive correlation between fetal weight and erythropoiesis has been observed at several stages of pregnancy $[4,32,33]$. These relationships suggest that in small fetuses, which are the most negatively affected by uterine crowding, there is an impairment in erythropoiesis. If the amount of EPOR gene expression by fetal liver reflects the number of red blood cell precursors that are resident in the fetal liver, or is indicative of fetal liver growth or maturation, these data could suggest that impairment of these processes could be a component of the negative impact of intrauterine crowding on erythropoiesis. Whether this observation has any direct impact on the physiology of the embryo/fetus or its survival is unknown. Further study into the expression of EPO and correlations with other fetal physiological parameters may be necessary to further associate pEPOR expression with erythropoiesis, crowding or litter size in swine.

Previous data suggest that fetal erythropoiesis in the Meishan breed may be accelerated compared to white crossbred pigs $[4,32]$. Data from this experiment suggest that changes in the ontogeny of the erythropoietin receptor is not a part of this accelerated development. Plasma erythropoietin also was not different between breeds. Changes in translation of the erythropoietin receptor mRNA or changes in effector molecules downstream of the receptor may be responsible for the acceleration of erythropoiesis observed in the Meishan.

In conclusion, our results indicate that the nucleotide and amino acid sequence of the pEPOR is very similar to other known EPOR and this similarity reaches into the noncoding regions, suggesting that these regions may be important in control of transcription, translation or stability of the mRNA. A dramatic increase in fetal liver EPOR mRNA occurs between Day 24 and 30 of pregnancy, likely coinciding with the onset of residency of erythrocyte precursors in the fetal liver. Results suggest that uterine crowding may impair fetal liver EPOR expression, possibly indicating a negative effect of uterine crowding on fetal erythropoiesis.

\section{Acknowledgments}

Names are necessary to report factually on available data; however, the USDA neither guarantees nor warrants the standard of the product, and the use of the same by USDA implies no approval of the product to the exclusion of others that may also be suitable.

The authors thank T. Alberts, F. Reno, D. Sypherd and K. Tennill for excellent technical support. 


\section{References}

[1] Wu MC, Chen ZY, Jarrell VL, Dzuik PJ. Effect of initial length of uterus per embryo on fetal survival and development in the pig. J Anim Sci 1989;67:1767-72.

[2] Vallet JL, Christenson RK. Uterine space affects placental protein secretion in swine. Biol Reprod 1993;48:575-84.

[3] Chen ZY, Dziuk PJ. Influence of initial length of uterus per embryo and gestation stage on prenatal survival, development, and sex ratio in the pig. J Anim Sci 1993;71:1895-901.

[4] Pearson PL, Klemcke HG, Christenson RK, Vallet JL. Uterine environment and breed effects on erythropoiesis and liver protein secretion in late embryonic and early fetal swine. Biol Reprod 1998;58:911-8.

[5] Fisher FW. Erythropoietin. Physiological and pharmacologic aspects. Proc Soc Exp Biol Med 1997;216: $358-69$.

[6] Bazan JF. A novel family of growth factor receptors: a common binding domain in the growth hormone, prolactin, erythropoietin and IL-6 receptors, and the p75 IL-2 receptor $\beta$-chain. Biochem Biophys Res Commun 1989;164:788-95.

[7] Jones SS, D'Andrea AD, Haines LL, Wong GG. Human erythropoietin receptor: cloning, expression and biological characterization. Blood 1990;76:31-5.

[8] Masuda S, Nagao M, Takaheta K, Konishi Y, Gallyas F, Tabira T, Sasaki R. Functional erythropoietin receptor of the cells with neural characteristics. Comparison with receptor properties of erythroid cells. J Biol Chem 1993;268:11208-16.

[9] D'Andrea AD, Lodish HF, Wong GG. Expression cloning of the murine erythropoietin receptor. Cell 1989;57:277-85.

[10] Lodish HF, Hilton DJ, Klingmuller U, Watowich SS, Wu H. The erythropoietin receptor: biogenesis, dimerization and intracellular signal transduction. Cold Spring Harbor Symposia on Quantitative Biology, Vol LX, p93-104, 1995. Cold Spring Harbor Laboratory Press.

[11] Lin CS, Lim SK, D'Agati V, Costantini F. Differential effects of an erythropoietin receptor gene disruption on primitive and definitive erythropoiesis. Genes and Develop 1996;10:154-64.

[12] Wu H, Liu X, Jaenisch R, Lodish HF. Generation of committed erythroid BFU-E and CFU-E progenitors does not require erythropoietin or the erythropoietin receptor. Cell 1995;83:59-67.

[13] Bolet G, Martinat-Botte F, Locatelli P, Gruand J, Terqui M, Berthelot F. Components of prolificacy in hyperprolific Large white sows compared with the Meishan and Large White breeds. Genet Sel Evol 1986;18:333-42.

[14] Christenson RK, Leymaster KA, Young LD. Justification of unilateral hysterectomy-ovariectomy as a model to evaluate uterine capacity in swine. J Anim Sci 1987;65:738-44.

[15] Vallet JL, Smith TPL, Sonstegard T, Pearson PL, Christenson RK, Klemcke HG. Isolation of cDNAs encoding putative secreted membrane-bound folate binding proteins from endometrium of swine. Biol Reprod 1999;61:372-9.

[16] Apte AN, Seibert PD. Anchor-ligated cDNA libraries: A technique for generating a cDNA library for the immediate cloning of the $5^{\prime}$ ends of mRNAs. Biotechniques 1993;15:890-3.

[17] Kozak M. An analysis of 5'-noncoding sequences from 699 vertebrate messenger RNAs. Nucleic Acids Res 1987; 15:8125-48.

[18] Middleton SA, Johnson DL, Jin R, McMahon FJ, Collins A, Tullai J, Gruninger RH, Jolliffe LK, Mulcahy LS. Identification of a critical ligand binding determinant of the human erythropoietin receptor. Evidence for common ligand binding motifs in the cytokine receptor family. J Biol Chem 1996;271:14045-54.

[19] Watowich SS, Liu KD, Xie X, Lai SY, Mikami A, Longmore GD, Goldsmith MA. Oligomerization and scaffolding functions of the erythropoietin receptor cytoplasmic tail. J Biol Chem 1999;274:5415-21.

[20] Yi T, Zhang J, Miura O, Ihle JN. Hematopoietic cell phosphatase associates with erythropoietin receptor after epo-induced receptor tyrosine phosphorylation: identification of potential binding sites. Blood 1995; 85:87-95. 
[21] Furukawa T, Narita M, Sakaur M, Otsuka T, Kuroha T, Masuko M, Azegami T, Kishi K, Takahashi M, Utsumi J, Koike T, Aizawa Y. Primary familial polycythemia associated with a novel point mutation in the erythropoietin receptor. Br J Hematol 1997;99:222-7.

[22] Sokol L, Luhory M, Guan Y, Prchal JF, Semenza GL, Prchal JT. Primary familial polycythemia: a frameshift mutation in the erythropoietin receptor gene and increased sensitivity of erythroid progenitors in erythropoietin. Blood 1995;86:15-22.

[23] Chapelle ADL, Traskelin A, Juvonen R. Truncated erythropoietin receptor causes dominantly inherited benign human erythrocytosis. Proc Natl Acad Sci USA 1993;90:4495-9.

[24] Prestridge DS. Signal scan: a computer program that scans DNA sequences for eukaryotic transcriptional elements. CABIOS 1991;7:203-6.

[25] Boissier F, Auge-Gouillou C, Schaeffer E, Zakin MM. The enhancer of the human transferrin gene is organized in two structural and functional domains. J Biol Chem 1991;266:9822-8.

[26] Dynan WS, Tjian R. Isolation of transcription factors that discriminate between different promoters recognized by RNA polymerase II. Cell 1983;32:669-80.

[27] Ohneda O, Yanai N, Obinata M. Erythropoietin as a mitogen for fetal liver stromal cells which support erythropoiesis. Exp Cell Res 1993;208:327-31.

[28] Nakamura Y, Nakauchi H. A truncated erythropoietin receptor and cell death: a reanalysis. Science 1994;264:588-9.

[29] Kuramochi S, Ikawa Y, Todokoro K. Characterization of murine erythropoietin receptor genes. J Mol Biol 1990;216:567-75.

[30] Fujita M, Takahashi R, Liang P, Saya H, Ashoori F, Tachi M, Kitazawa S, Maeda S. Role of alternative splicing of the rat erythroietin receptor gene in normal and erythroleukemia cells. Leukemia 1997;11(Suppl 3):S444-S445.

[31] Nakamura Y, Tokumoto Y, Nakauchi H. Role of a truncated erythroietin receptor for erythroid differentiation. Biochem Biophys Res Horm 1996;218:205-9.

[32] Vallet JL, Klemcke HG, Pearson PL, Christenson RK. Effect of intrauterine crowding and breed of fetal erythropoiesis on day 35 of pregnancy in swine. Biol Reprod 1999;60(Suppl 1):S126-S127.

[33] Vallet JL, Rohrer GA, Klemcke HG, Christenson RK. Factors affecting fetal hematocrit (HC) and fetal plasma iron (PI) at $105 \mathrm{~d}$ of gestation in swine. J Anim Sci 1999;77(Suppl 1):S219. 